\title{
The role of let-7 in cell differentiation and cancer
}

\author{
Benjamin Boyerinas, Sun-Mi Park, Annika Hau, Andrea E Murmann \\ and Marcus E Peter
}

The Ben May Department for Cancer Research, The University of Chicago, 924 E 57th Street, Chicago, Illinois 60637, USA

(Correspondence should be addressed to M E Peter; Email: mpeter@uchicago.edu)

\begin{abstract}
MicroRNAs (miRNAs or miRs) are small noncoding RNAs capable of regulating gene expression at the translational level. Current evidence suggests that a significant portion of the human genome is regulated by microRNAs, and many reports have demonstrated that microRNA expression is deregulated in human cancer. The let-7 family of microRNAs, first discovered in Caenorhabditis elegans, is functionally conserved from worms to humans. The human let-7 family contains 13 members located on nine different chromosomes, and many human cancers have deregulated let-7 expression. A growing body of evidence suggests that restoration of let-7 expression may be a useful therapeutic option in cancers, where its expression has been lost. In this review, we discuss the role of let-7 in normal development and differentiation, and provide an overview of the relationship between deregulated let-7 expression and tumorigenesis. The regulation of let-7 expression, cancer-relevant let-7 targets, and the relationship between let-7 and drug sensitivity are highlighted.
\end{abstract}

Endocrine-Related Cancer (2010) 17 F19-F36

\section{Introduction}

The discovery of microRNAs (miRNAs or miRs) in the early 1990s has opened a new era understanding posttranscriptional regulation of genes by small RNAs (Lee et al. 1993). miRs are small noncoding RNAs known to repress target gene expression by binding to complementary sequences found in the $3^{\prime}$-untranslated region (UTRs) of target mRNAs. They form an important class of regulators that participate in diverse biological functions including development, cell proliferation, differentiation, and apoptosis (Jovanovic \& Hengartner 2006, Bussing et al. 2008, Schickel et al. 2008, Stefani \& Slack 2008). In respect to their diverse functions, miRs are also known to be involved in many diseases including cancer (Alvarez-Garcia \& Miska 2005, Kent \& Mendell 2006).

Most miRs are initially transcribed by RNA polymerase II from the genome as long primary

This paper is one of 6 papers that form part of a special Focus Section on microRNAs. The Guest Editors for this section were Professor Alfredo Fusco, Naples, Italy, and Professor Carlo M Croce, Columbus, $\mathrm{OH}$, USA. transcripts (pri-miRs), which range in size from hundreds of bases to several kilobases (Cullen 2004). These transcripts are first processed by the microprocessor complex containing the RNase-III enzyme Drosha and the double-stranded RNA-binding protein Pasha (DGCR8) to precursor miRs (pre-miR), which are about 60-70 nucleotides long (Lee et al. 2003). The premiRs are exported from the nucleus to the cytoplasm by a Ran-GTP transporter known as exportin-5 (Yi et al. 2003). In the cytoplasm, the pre-miRs are further processed by a second RNase-III enzyme known as Dicer (which complexes with TRBP and Ago2) to mature miRs with a length of 20-22 nucleotides (Hutvagner et al. 2001, Ketting et al. 2001). Mature miRs are then incorporated into the miR RNA-induced silencing complex that binds to target mRNAs leading to translational repression or mRNA cleavage (Lai 2002).

\section{The discovery of let-7 and its role in development}

Although let-7 was found as the second miR after lin-4 in Caenorhabditis elegans (Reinhart et al. 2000), its high conservation across the animal phylogeny from 
C. elegans to human provided the clue for the generality of miRs as essential regulators of gene expression in various organisms (Pasquinelli et al. 2000). This has led to the isolation of numerous miRs by the Ambros, Tuschl, and Bartel groups (Lagos-Quintana et al. 2001, Lau et al. 2001, Lee \& Ambros 2001). Owing to recent cloning and computational efforts, the numbers of known miRs has been rapidly increasing, and to date, there are a total of 9169 mature miRs found across 103 species, of which 885 miRs are found in humans (miRBase Release $13.0 \mathrm{http}: / /$ microrna.sanger.ac.uk/sequences). Many of these miRs are highly conserved across species, suggesting that miRs are an integral part of essential cellular processes. A good example is the let-7 family of miRs, which is highly conserved across diverse animal species from worms to humans (Pasquinelli et al. 2000). Consistent with its role in regulating cell proliferation and differentiation during development in different species, the deregulation of this miR has been shown as a feature of many types of cancer, reflecting the major conserved roles of let-7.

Let-7 was initially identified as a heterochronic gene by forward genetics in C. elegans (Reinhart et al. 2000). During C. elegans development, the hypodermal skin cells known as seam cells undergo asymmetrical division at each larval stage. At the larval 4 to adult transition, these cells stop dividing, terminally differentiate, and secrete ridges called alae. Let-7 mutant worms display abnormalities in the pattern of temporal development by reiterating their fourth larval cell fates at the adult stage (Reinhart et al. 2000). The seam cells fail to differentiate and exit cell cycle leading to extra seam cell divisions and lack of alae formation. Eventually, many of these mutant worms die by bursting of the vulva, thus giving the let-7 gene its name - lethal-7. The timing of the phenotype of the let-7 mutant corresponds with the expression of let-7, which can be detected at L3 and reaches maximum at L4 stage (Reinhart et al. 2000, Esquela-Kerscher et al. 2005). Studies manipulating let-7 expression have confirmed the essential role of let-7 in the transition from larval 4 stage to adult stage. Fusing the let 7 gene to the lin-4 gene and directing let-7 expression at larval stage 2 was shown to lead to precocious adult development at L4 stage, demonstrating that expression of let-7 is sufficient to specify adult fate in the worm (Hayes \& Ruvkun 2006).

Other miRs that share the similar seed sequence as let-7 in C. elegans are mir-48, mir-84, mir-241, mir-265, mir-793, mir-794, mir-795, and mir-1821 (Roush \& Slack 2008). Nothing is known about the developmental expression and functions for mir-793, mir-794, mir-795, and mir-1821. Similar to let-7, mir-48, mir-84, and mir-241 are members of the heterochronic pathway, functioning in the regulation of temporal patterning at the transition from L2 to L3 stage (Abbott et al. 2005). This is consistent with their earlier expression, which begins at early L1 for mir-84, and at L2 for both mir-48 and mir-241, which in all cases increase over the course of development (Esquela-Kerscher et al. 2005, Li et al. 2005). Single mutants for mir-84 and mir-241 display normal phenotypes, whereas the mir- 48 single mutants exhibit a weak retarded defect of extra molting at the adult stage (Abbott et al. 2005). The penetrance of this retarded molting defect was enhanced in mir-48/mir-84 double mutants. The mir-48/mir-241 double mutants have a retarded seam cell phenotype in which seam cells undergo an extra cell division during the L3 stage. These double mutants also display incomplete alae formation and lethality associated with vulval bursting at the L4 to adult transition. These defects occur with higher penetrance in the triple mutants compared to the double mutants, indicating functional cooperation among these three miRs (Abbott et al. 2005).

Let-7, mir-48, mir-84, and mir-241 are expressed at different times during development (Reinhart et al. 2000, Esquela-Kerscher et al. 2005). Lin-4 and nuclear receptor dauer formation-12 (DAF-12) mutants have reduced levels of the mature forms of these miRs (Esquela-Kerscher et al. 2005). Recently, DAF-12 and its steroid ligand have been shown to directly activate promoters of mir-84 and mir-241, which leads to downregulation of their target, hunchback-like (HBL)-1, allowing L2 to L3 transition (Bethke et al. 2009). DAF-12 itself is a target of let-7 at later stages, indicating that feed forward and feedback loops are involved in driving different stage transitions (Grosshans et al. 2005). While DAF-12 seems to be a nematode-specific let-7 target, other targets such as RAS (homolog of let-60) and TRIM71 (lin-41) are conserved among various organisms (Kloosterman et al. 2004, Johnson et al. 2005, Schulman et al. 2005, Lin et al. 2007, Yu et al. 2007a, O'Farrell et al. 2008).

Recent studies in Drosophila have shown that let-7 also functions as a heterochronic gene in this species (Caygill \& Johnston 2008, Sokol et al. 2008). In Drosophila, there is only a single let-7 gene (Lagos-Quintana et al. 2001), and it becomes expressed at the end of the third larval instar stage and peaks in pupae during metamorphogenesis (Pasquinelli et al. 2000, Bashirullah et al. 2003). Like C. elegans, Drosophila undergo a series of molting processes in their development, and a pulse 
of ecdysone is released before each molting stage. The temporal expression of let-7 coincides with the release of ecdysone, but whether ecdysone regulates the expression of let-7 is still unclear (Sempere et al. 2002, Bashirullah et al. 2003). Recent studies have shown that let-7 mutants display a temporal delay in the terminal cell cycle exit in the wing and also have defects in maturation of neuromuscular junctions at adult abdominal muscles (Caygill \& Johnston 2008, Sokol et al. 2008). The mutants exhibit clear juvenile features in their neuromusculature, and these lead to defects in adult behaviors such as flight, motility, and fertility (Sokol et al. 2008). Therefore, let-7 expression ensures the appropriate remodeling of the abdominal neuromusculature during the larval to adult transition serving as a conserved regulator of events necessary for the transition from juvenile to adult life stages.

There are 14 and 13 different let-7 family members in mouse and human respectively (Roush \& Slack 2008). In human, these different members are let-7a-1, $7 a-2,7 a-3,7 b, 7 c, 7 d, 7 e, f 7-1,7 f-2,7 g, 7 i$, mir-98, and mir-202 (Ruby et al. 2006). Among the members, let-7a has identical sequence across various animal species from C. elegans to human. The increase in let-7 expression in late developmental stages has been reported in many organisms (Sempere et al. 2002, Lancman et al. 2005, Liu et al. 2007, Wulczyn et al. 2007). Previously, studies have shown the expression patterns of let-7 in vertebrates during development; however, the direct contribution of let-7 in development has not been demonstrated (Lancman et al. 2005, Schulman et al. 2005, Wulczyn et al. 2007). This is probably because vertebrate let-7 family members are likely to have redundant roles, and it is technically challenging to knock out all the members of the let-7 family in the same animal.

As demonstrated by its role in seam cell differentiation at the larval to adult transition in C. elegans, a major role of let-7 is to promote differentiation of cells. In mammals, let-7 levels increase during embryogenesis and during brain development (Schulman et al. 2005, Wulczyn et al. 2007). Let-7 is undetectable in human and mouse embryonic stem cells, and the level of let-7 increases upon differentiation (Thomson et al. 2004, 2006, Wulczyn et al. 2007). This high expression of let-7 is then maintained in various adult tissues (Sempere et al. 2004, Thomson et al. 2004). Conversely, the reduction of let-7 levels has been found in many human cancers, which is reflective of the reverse embryogenesis process that occurs during tumorigenesis (Park et al. 2007). As we will discuss in the following, while let-7 was initially viewed as one single activity, emerging data suggest that the let-7 family contains miRs with different activities. We will therefore wherever possible name the specific let-7 family members throughout this review.

\section{Deregulation of let-7 family members in different cancer types}

Let-7 is widely viewed as a tumor suppressor miR. Consistent with this activity, the expression of let-7 family members is downregulated in many cancer types when compared to normal tissue and during tumor progression. For some forms of cancer, most or all let-7 family members appear to be downregulated (Takamizawa et al. 2004, Dahiya et al. 2008, O'Hara et al. 2009). However, downregulation of specific family members in various cancers has also been described and is summarized in Table 1. The loss of let-7 family members also has prognostic value as it indicates poor survival. A general downregulation of let-7 was found to correlate with poor survival in lung cancer (Takamizawa et al. 2004). Specifically, this was also reported for let-7a-2 (Yanaihara et al. 2006). Low expression of let-7d (combined with low miR-205 expression) was found in head and neck squamous cell carcinoma (HNSCC) patients, and was predictive of poor survival (Childs et al. 2009), and a combined loss of let-7d with an increase in expression of the let-7 target high mobility group 2A (HMGA2) was indicative of poor survival in ovarian cancer (Shell et al. 2007).

Although less frequent, upregulation of certain let-7 family members has also been observed, suggesting that let-7 does not play a tumor suppressor function under all circumstances and/or in all tissues (Table 1). The upregulation of let- $7 \mathrm{~b}$ and let-7i was associated with high grade transformation in lymphoma (Lawrie et al. 2008), indicating that increased expression of let-7 family members could be used as a prognostic marker to identify patients at risk of high grade transformation, or for higher grade cancer. The most detailed mechanistic analysis of an up-regulated let-7 family member was performed for let-7a-3. Hypomethylation of the let-7a-3 locus was found to cause higher expression of let-7a-3 in epithelial ovarian cancer (Lu et al. 2007) and lung cancer (Brueckner et al. 2007). Hypomethylation did not only cause increased expression of let-7a-3, but subsequently deregulated the expression of other genes, including oncogenes and genes involved in cell proliferation, adhesion, and differentiation (Brueckner et al. 2007).

The conflicting data on the deregulation of let-7 in various cancers indicate that the function of the let-7 
Table 1 Changes in the expression of let-7 family members in human cancer

\begin{tabular}{|c|c|c|c|}
\hline $\begin{array}{l}\text { Family } \\
\text { member }\end{array}$ & $\begin{array}{l}\text { Cancer type } \\
\text { downregulated }\end{array}$ & $\begin{array}{l}\text { Cancer type } \\
\text { up-regulated }\end{array}$ & Reference \\
\hline \multirow[t]{8}{*}{$7 a$} & Breast & & Sempere et al. (2007) \\
\hline & Lung & & $\begin{array}{l}\text { Takamizawa et al. (2004), Johnson et al. } \\
\text { (2005), and Yanaihara et al. (2006) }\end{array}$ \\
\hline & Melanoma & & Muller \& Bosserhoff (2008) \\
\hline & Pancreatic & & Torrisani et al. (2009) \\
\hline & PPNAD & & Iliopoulos et al. (2009) \\
\hline & & Lung $^{\mathrm{a}}$ & Brueckner et al. (2007) \\
\hline & & Lymphoma & Nie et al. (2008) \\
\hline & & Ovarian $^{\mathrm{a}}$ & Lu et al. (2007) \\
\hline \multirow[t]{8}{*}{$7 \mathrm{~b}$} & ALL & & Mi et al. (2007) \\
\hline & Melanoma & & Schultz et al. (2008) \\
\hline & Ovarian & & Nam et al. (2008) \\
\hline & PPNAD & & Iliopoulos et al. (2009) \\
\hline & Prostate & & Ozen et al. (2008) \\
\hline & Retinoblastoma & & Huang et al. (2007) \\
\hline & & GIST & Subramanian et al. (2008) \\
\hline & & Lymphoma & Lawrie et al. (2008) \\
\hline \multirow[t]{4}{*}{$7 c$} & Burkitt lymphoma $^{\mathrm{b}}$ & & Leucci et al. (2008) \\
\hline & Lung & & 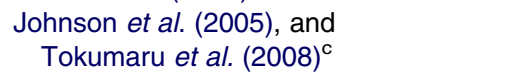 \\
\hline & PPNAD & & Iliopoulos et al. (2009) \\
\hline & Prostate & & Ozen et al. (2008) \\
\hline \multirow[t]{3}{*}{$7 d$} & HNSCC & & Childs et al. (2009) \\
\hline & Ovarian & & $\begin{array}{l}\text { Shell et al. (2007), and } \\
\text { Dahiya et al. (2008) }\end{array}$ \\
\hline & Prostate & & Ozen et al. (2008) \\
\hline \multirow[t]{2}{*}{$7 e$} & Ovarian & & Dahiya et al. (2008) \\
\hline & Prostate & & Ozen et al. (2008) \\
\hline \multirow[t]{5}{*}{$7 f$} & Lung & & Takamizawa et al. (2004) \\
\hline & Ovarian & & Dahiya et al. (2008) \\
\hline & Prostate & & Ozen et al. (2008) \\
\hline & Sarcoma & & Subramanian et al. (2008) \\
\hline & & Breast & Yan et al. (2008) \\
\hline \multirow[t]{3}{*}{$7 g$} & Lung & & Johnson et al. (2005) \\
\hline & PPNAD & & Iliopoulos et al. (2009) \\
\hline & Prostate & & Ozen et al. (2008) \\
\hline \multirow[t]{4}{*}{$7 \mathrm{i}$} & Ovarian & & Yang et al. $(2008 b)$ \\
\hline & Prostate & & Ozen et al. (2008) \\
\hline & & HNSCC & Chang et al. (2008a) \\
\hline & & Lymphoma & Lawrie et al. (2008) \\
\hline $7 b^{*}$ & & Mesothelioma & Guled et al. (2009) \\
\hline $7 e^{\star}$ & Mesothelioma & & Guled et al. (2009) \\
\hline miR-98 & & Breast & Yan et al. (2008) \\
\hline
\end{tabular}

PPNAD, primary pigmented nodular adrenocortical disease; ALL, acute lymphoblastic leukemia; GIST, gastrointestinal stromal tumors; HNSCC, head and neck squamous cell carcinoma.

aLet-7a-3.

${ }^{\mathrm{b}}$ Negative for c-myc translocation.

${ }^{\mathrm{C} C a u s e d ~ b y ~ g e n e t i c ~ l o s s ~ o f ~ 21 q 11-q 21 . ~}$

family is not clearly defined, or that individual let-7 family members can have different activities. While the different family members are currently being viewed as targeting a highly overlapping set of targets, it is conceivable that the 13 let- 7 genes do not exist simply to have different functions in different tissues but because two let-7 family members could have different functions in the same cell. Consistent with this prediction are occasional reports of cancers in which certain let-7 species are up-regulated, while others are lost. An example of this is a report on malignant mesothelioma, where let- $7 b^{*}$ was found to be highly expressed but let-7e* was severely reduced (Guled et al. 2009). Cases such as this suggest that let-7 
family members are potentially subject to differential regulation within the same cell, and an important area the miR field will need to address is whether different family members indeed have specific activities in a particular cell type, or whether tissue-specific regulation is the most important mechanism utilized to obtain specific let-7-mediated cellular outcomes regardless of which let-7 member is involved.

\section{Cancer-relevant let-7 targets}

The first mammalian target of let-7 was identified by virtue of evolutionary sequence conservation between the nematode $C$. elegans and humans. Using a computational screen for $C$. elegans $3^{\prime}$-UTR sequences containing let-7 family complementary sites (LCS), Johnson et al. (2005) identified let-60 as a top-scoring candidate whose human ortholog is the three RAS oncogenes that are frequently deregulated in many human cancers. It was determined that let- 60 expression is tightly and directly regulated by miR- 84 in C. elegans vulval cells, and it was also demonstrated that human let-7 does specifically target RAS in human cancer cells. The same group determined that let-7 family members $7 \mathrm{a}, 7 \mathrm{c}$, and $7 \mathrm{~g}$ are significantly decreased in lung cancer tumors, and that many let-7 family members are located in genomic regions frequently deleted in lung cancer patients. This evidence, together with the fact that RAS is frequently up-regulated in human lung tumor samples, suggested a pivotal role for the let-7 family in the suppression of oncogenic RAS proteins in vivo. This direct targeting of RAS by let-7 was confirmed in nonsmall cell lung cancer (NSCLC), where it was demonstrated in a mouse model that let-7g inhibited tumor growth via suppression of RAS (Kumar et al. 2008).

Single nucleotide polymorphisms (SNPs) within the $3^{\prime}$-UTRs of target genes have only recently been implicated in miR-mediated control of gene expression. Weidhaas et al. investigated whether Kirsten rat sarcoma viral oncogene homolog (KRAS) LCS contained SNPs that could affect miR binding (Chin et al. 2008). They identified a variant allele in one of the ten KRAS LCS sequences (KRAS LCS6), which was found to be significantly higher in NSCLC patients than in healthy individuals (5.8\% healthy, 20.3\% NSCLC as per Yale University DNA collection) and predicted for an increased risk of developing NSCLC for moderate smokers. Another report concerning the LCS6 SNP in RAS came from studies of HNSCC, where this allele is associated with poorer patient survival but does not confer increased risk to HNSCC. Survival was reduced most significantly in oral cancer patients, suggesting the LCS6 polymorphism might be important when considering therapeutic approaches for these patients (Christensen et al. 2009). Recently, the Kras 3'-UTR SNP was also linked to an increased risk of developing ovarian cancer (J Weidhaas, I Babar, S M Nallur, P Trang, S Roush, M Boehm, E Gillespie, F J Slack, personal communication).

The second major let-7 target identified was HMGA2, which is a chromatin-associated nonhistone protein capable of modulating chromatin architecture and thus affecting transcription. It is a gene with an oncofetal pattern of expression and is widely expressed in undifferentiated embryonal tissues but undetectable in normal adult tissues. Its importance during animal development was revealed by hmga 2 knockout mice, which display mesenchymal tissue hypoplasia leading to a pygmy phenotype (Zhou et al. 1995). In addition to its role during embryogenesis, HMGA2 is expressed in both benign and malignant tumors mostly due to deregulation via chromosomal aberrations on 12q13-15. These rearrangements are known to truncate the HMGA2 open reading frame (ORF) releasing the DNA-binding domain from the adjacent acidic domain, and this rearrangement is associated with oncogenic transformation. However, in addition to ORF truncation, the separation of the regulatory $3^{\prime}$-UTR region from the intact HMGA2 coding sequence is also known to have similar neoplastic effects in human tumors and a transgenic mouse model, suggesting that control of HMGA2 expression via the $3^{\prime}$-UTR is an important control mechanism. HMGA2 translocations also recurrently involve fusion of the HMGA2 $3^{\prime}$-UTR to known tumor suppressor genes such as FHIT, RAD51L1, and HEI10, and let-7-mediated repression of these genes might enhance the oncogenic potential of such rearrangements (Mayr et al. 2007).

Multiple lines of initial evidence suggested that HMGA2 might be a direct let-7 target gene. The $3^{\prime}$-UTR of HMGA2 contains multiple let-7 complementarity sites; it is downregulated during embryogenesis coinciding with concomitant let-7 upregulation, and it was shown to be up-regulated in lung cancer - a cancer known for its lowered let-7 expression. Data published by three groups (Lee \& Dutta 2007, Mayr et al. 2007, Shell et al. 2007) confirmed HMGA2 as a direct let-7 target both in vitro and in vivo. Mayr et al. demonstrated that the truncated form of HMGA2 is uncoupled from let-7-induced growth suppression, and that this protein has oncogenic properties when expressed in NIH3T3 cells, which express endogenous levels of let-7. The same aggressiveness was also seen in vivo with injection of cells expressing the truncated HMGA2 protein. It was demonstrated in ovarian 
cancer patients that the ratio of let- 7 to HMGA2 was useful as a prognostic marker, with a lower ratio predicting shorter overall survival (Shell et al. 2007). Interestingly, there are also reports linking RAS with HMGA2, in the maintenance of a mesenchymal phenotype. In a study by Watanabe et al. (2009), oncogenic RAS signaling was found to induce HMGA2 expression and thus inhibit the epithelial phenotype of pancreatic cancer cells.

In addition to aberrant expression in lung and ovarian cancer, HMGA2 is frequently elevated in uterine leiomyomas where higher expression of HMGA2 and lower expression of let-7 correlate with larger tumor size (Peng et al. 2008). HMGA2 overexpression is also seen in pituitary adenomas, which are neoplastic intracranial tumors that frequently have deregulated let-7 expression. In a recent study, 39\% of pituitary adenomas analyzed had significantly higher HMGA2 expression, which correlated with higher tumor grade and tumor invasiveness (Qian et al. 2009). A significant inverse correlation between HMGA2 and let-7 expression was observed in these tumors, suggesting that loss of let-7 expression contributes to the aggressive phenotype of these cancers via re-expression of HMGA2.

As mentioned above, hmga2 knockout mice were found to display many of the principal features of the pygmy phenotype (Zhou et al. 1995). The stunted growth of these animals was also found to be semi-dominant with heterozygous animals weighing $80 \%$ of their wild-type littermates. These data are in accordance with more recent data where HMGA2 expression levels have been shown to correlate with larger tumor size (Peng et al. 2008), and a truncated HMGA2 has been shown to correlate with larger body size (Nishino et al. 2008) and reduced adult human height (Lettre et al. 2008). While this phenotype can be explained in multiple ways, it is potentially suggestive of a defect in the stem cell compartment. In an interesting new development, evidence has begun to link lack of let-7 expression to the maintenance of the stem cell phenotype (Peter 2009). A study investigating breast cancer tumor-initiating cells (T-ICs) determined that they are let-7 low, and that HMGA2 is important for maintaining their pluripotency (Yu et al. 2007a). It was also determined that low let-7 expression characterizes mouse mammary epithelial progenitor cells that have many of the characteristics of murine stem cells and can completely repopulate the mammary tree from single cells (Ibarra et al. 2007). This evidence suggests that major let-7 targets, including HMGA2, might be participating in maintenance of a stem cell phenotype. Interestingly, HMGA2 was the major differentially expressed gene found using a genome-wide analysis of murine neural stem cells during aging (Nishino et al. 2008). The expression of HMGA2 was reduced in neural stem cells in an age-dependent manner, and this coincided with induction of let-7b. HMGA2 expression was not necessary for stem cell formation, but it was paramount to maintaining self-renewal potential of young stem cells. This maintenance of stemness was dependent on HMGA2 negatively regulating $\mathrm{p} 16^{\text {Ink }}$ and $\mathrm{p} 19^{\mathrm{Arf}}$, two important negative regulators of cell cycle progression.

The regulation of HMGA2 by let-7 is not only pivotal in maintaining tissue homeostasis, but it has recently been implicated in other cellular functions. Mouse adipogenesis relies on the clonal expansion of undifferentiated cells upon adipogenic stimuli, cell cycle exit, and subsequent terminal differentiation. Recently, it was demonstrated that during transition from expansion to differentiation, let- $7 \mathrm{c}$ and let- $7 \mathrm{~b}$ are significantly up-regulated and maintained at elevated levels in mature adipocytes (Sun et al. 2009). This differentiation relies on loss of HMGA2, which had previously been implicated in adipogenesis. Mice lacking HMGA2 have reduced adipose tissue, whereas animals overexpressing a truncated HMGA2 have an increased amount of fat tissue (Zhou et al. 1995). Indeed, in adipocytes treated with let-7a, the most markedly reduced gene is HMGA2, and siRNAmediated knockdown of HMGA2 prevents adipocyte differentiation. Determination of adult height in humans is a highly variant polygenic trait regulated by multiple genes by a largely unknown synergistic mechanism. Genome wide association studies were used to identify ten loci associated with height determination where two SNPs were robustly associated with adult height variation (Lettre et al. 2008). One of these SNPs is located in the $3^{\prime}$ UTR of HMGA2 very close to a binding site of let-7 possibly abolishing let-7 binding to this site. In addition to the highly predictive SNP in HMGA2, three other let-7 targets are among the ten loci identified. These additional genes are CKD6 (important in cell cycle regulation), DOT1L (histone methyltransferase), and LIN28B (let-7 regulation).

Our group has recently identified 12 cancer-relevant let-7 regulated oncofetal genes (LOGs; Boyerinas et al. 2008). This study looked at the overlap between genes predicted to be let-7 targets by target prediction algorithms, genes experimentally shown to be downregulated when let-7 was overexpressed in two cancer cell lines, and genes downregulated at the time during murine embryonic development when let-7 is drastically up-regulated. Twelve genes met these criteria, and eight of the twelve had been previously implicated in cancer formation or development. LOG \#1 was HMGA2, LOG \#2 was IGF2 mRNA-binding protein 
(IMP)-1, and LOG \#3 was LIN28B (which will be discussed in detail later). IMP-1 (also known as insulin-like growth factor protein 1 and CRD-BP) is an RNA-binding protein with a known oncofetal pattern of expression that had previously been linked to multiple forms of cancer. We experimentally validated IMP-1 as a let-7 target and determined that it was an important target gene for let-7-mediated inhibition of growth and invasiveness in let-7 low cancer cell lines. We hypothesize that many of the LOGs become re-expressed in cancers that lose let-7 expression, and that this process can be considered a form of reverse embryogenesis.

Though the vast majority of let-7 targets seem to have oncogenic properties with let-7 acting as a tumor suppressor, recent reports also attribute an oncogenic role to let-7a. Caspase-3, a pivotal protease activated during apoptosis, contains let-7a seed matches, and it was determined that let-7a specifically targets caspase3 mRNA in cancer cell lines (Tsang \& Kwok 2008). Taken together with previously published data where the let-7a-3 locus was found to be hypomethylated in human lung adenocarcinomas (Brueckner et al. 2007), these results raise the possibility that let-7a acts in an oncogenic manner.

Another scenario where let-7 acts in an oncogenic fashion involves the transcriptional repressor Blimp-1 (also known as PRDM1). This factor is important for terminal differentiation of lymphocytes and epidermal cells, and is considered a crucial determinant in plasma cell differentiation. Loss of Blimp-1 expression has been described as a characteristic event in Hodgkin lymphoma and other human lymphomas. The reduced expression of Blimp-1 was determined to be the result of upregulation of two miRs able to engage the Blimp1 mRNA; the endogenous miRs miR-9 and let-7a (Nie et al. 2008). Downregulation of Blimp-1 by let-7a suggests an oncogenic role for this miR in these cells, as this enables inappropriate and potentially neoplastic cell division. There are, however, reports on let-7a conferring anti-neoplastic protection by counteracting c-Myc-induced growth in Burkitt lymphoma. Exogenously overexpressed let-7a caused a significant repression of Myc levels, and this led to reduced proliferation in lymphoma cells in vitro (Sampson et al. 2007). These data suggest that the cellular response to let-7a may be dependent on cell context in much the same way that p53 activation elicits drastically different results in different cell types.

There are some interesting recent reports detailing negative feedback loops involving Dicer, the RNAse III nuclease known to process pre-miR, and let-7. Identified as a putative let-7d target by the target algorithm PicTar, the inverse correlation of let-7a and Dicer was confirmed in a panel of 20 cell lines whilst Drosha, the RNAse involved in the processing of pri-miR molecules, did not correlate with let-7 expression (Tokumaru et al. 2008). Dicer was confirmed as a direct target of let-7a, and exogenous expression of let- $7 \mathrm{a},-7 \mathrm{c}$, or $-7 \mathrm{~d}$ was shown to be sufficient for the marked downregulation of Dicer mRNA and protein. This decrease in Dicer does not only negatively affect the processing of let-7 family members but rather has a broad effect on the processing of many other miRs in both normal and cancer cell lines. Importantly, reduced expression of Dicer has been associated with poor prognostic outcome in NSCLCs (Tokumaru et al. 2008). The regulation of Dicer through its $3^{\prime}$-UTR is not the only mechanism by which the let-7 family controls the expression of this nuclease. In a screen for putative miR-targeting sites in the ORFs of protein-coding genes, LCS's were found to be the single most highly conserved sequences identified. Among genes containing these ORF targeting motifs, the Dicer ORF was found to contain three let-7 target sites leading to it being efficiently downregulated by exogenous expression of let-7 (Forman et al. 2008).

Repression of let-7 targets does not rely solely on the activity of the miR alone. The transcription factor $\mathrm{c}-\mathrm{Myc}$ is also repressed in an interdependent manner by let- $7 \mathrm{~b} / \mathrm{c}$ and the RNA-binding protein Human antigen $\mathrm{R}$ (HuR; Kim et al. 2009). This regulation relies on the binding of HuR to the $3^{\prime}$-UTR of c-Myc leading to the recruitment of let-7 loaded RISC complexes to the adjacent let-7 target site. This concerted binding leads to the efficient degradation of the c-Myc mRNA in an Ago2-dependent way. This additional layer of regulation to let-7 targeting is likely only one example of protein-mediated control of miR function.

Let-7 has been linked to a number of cellular responses that could be exploited for cancer therapy, including regulation of cellular proliferation $(\mathrm{Gu} \&$ Iyer 2006). Overexpression of let-7a, 7b, and 7c were shown to inhibit the growth of cancer cell lines (Johnson et al. 2007), and one way that let-7 negatively regulates growth is by inhibiting protein translation (Ding et al. 2008). A mechanism to explain this activity is the specific targeting of eIF4F by let-7a (Mathonnet et al. 2007). However, an alternative mechanism involves degradation of various cell cycle regulators (Johnson et al. 2007), which was specifically demonstrated for let-7b in melanoma cells (Schultz et al. 2008). However, this activity of let-7 may not be tumor cell specific since in primary fibroblasts let- $7 \mathrm{~b}$ was shown to cause $\mathrm{G} 2 / \mathrm{M}$ arrest through targeting 
Cdc34 resulting in the stabilization of the Wee1 kinase (Legesse-Miller et al. 2009). Finally, let-7f and $7 \mathrm{~g}$ have been shown to be up-regulated in cells with induced premature senescence (Maes et al. 2009), and let- $7 \mathrm{f}$ was found to be up-regulated during replicative senescence of mesenchymal stem cells (Wagner et al. 2008). Let-7's role in regulating senescence is consistent with the function of one of its main targets, HMGA2, in this process (Narita et al. 2006).

First attempts to utilize the apparent anticancer activity of let-7 for therapeutic purposes have been made by two groups who used let-7b, $7 \mathrm{c}, 7 \mathrm{~g}$, and let- $7 \mathrm{~g}$ respectively to slow tumor formation in a mouse lung cancer model (Esquela-Kerscher et al. 2008, Kumar et al. 2008). However, a more recent study on pancreatic cancer suggested that while let-7a affected proliferation of cancer cells in vitro, this did not translate into reduced tumor growth in vivo (Torrisani et al. 2009). It is important to note that the activity of let-7 to reduce tumor growth in vivo is dependent upon the particular cellular context. While in proliferating cells it inhibits translation, in cells arrested in the cell cycle let-7 can actually induce translation (Vasudevan et al. 2007). These data demonstrate that more research is needed into the specific activities of the let-7 family before let- 7 can be utilized in a therapeutic context.

\section{The regulation of let-7 expression in cancer}

It has been reported that miRs are globally downregulated during cancer formation (Lu et al. 2005, Thomson et al. 2006). In addition to this global effect, expression of miRs with specific tumor suppressor activities is lost in many forms of cancer. Let-7 is a marker of fully differentiated cells, and it is undetectable in stem cells (Ibarra et al. 2007). Many of the targets of let-7 have activities in stem cells, and the expression of let-7 must therefore be carefully controlled (Peter 2009). Different levels of regulation in the biogenesis of let-7 have recently emerged revealing an intricate regulatory loop comprising let-7 and some of its targets with stem cell activity.

First evidence of extensive posttranscriptional regulation of let-7 came from studies of mouse embryonic development. Both in the developing brain and the entire mouse, mature let- 7 was found to be absent early during development (Thomson et al. 2006, Wulczyn et al. 2007). In contrast, the primary transcript of let-7 was expressed at high levels at these stages. An inverse situation was found in cancer where cancer cells that had lost expression of mature let-7 still expressed the primary transcript (Thomson et al.
2006). These data suggested the existence of a regulatory mechanism that affected the biogenesis of let-7 either at the Drosha or Dicer level, or at the level of export of pre-let-7 to the cytosol. Because this effect was selective for let-7 family members, it was assumed that a protein factor could selectively inhibit the processing of let-7 during development. Two groups set out to biochemically identify this factor from differentiating P19 embryonic stem cells by coupling pre-let-7 molecules to beads and pulling down proteins that bound to the loop region of let-7 (Newman et al. 2008, Viswanathan et al. 2008). In both cases, two proteins were identified using mass spectrometry Lin28 and Lin28B. Both these proteins were found to be selective in their ability to block processing of let-7 family members (Fig. 1). However, the two groups came to different conclusions as to the mechanisms of action. The Hammond group tested various let-7 family members and concluded that Lin28/Lin28B act at the level of Drosha, whereas the Gregory group, mostly focusing on let-7a and $\mathrm{g}$, identified Dicer as the site of action. In any case, the identification of Lin28/ Lin28B as a regulator of let-7 processing represents a major breakthrough in our understanding of how let-7 expression is regulated during both embryonic development and cancer progression. In a subsequent biochemical study, it was shown in detail how Lin28 binds to the terminal loop region of let-7g (Piskounova et al. 2008). Both cold shock domains and both zinc finger domains in Lin28 are involved in the binding, resulting in more than $90 \%$ inhibition of let- $7 \mathrm{~g}$ processing upon upregulation of Lin28.

More recently, a third mechanism of how Lin28/Lin28B block let-7 processing was discovered (Fig. 1). It was found that in cells with blocked let-7 processing, pre-let-7 was posttranscriptionally modified and carried a 14-nt long extension mostly comprising uridine (Heo et al. 2008). This polyuridylation resulted in degradation of pre-let-7. Recently, the terminal uridylyl transferase (TUTase) was identified as TUT4 (also known as ZCCHC11; Hagan et al. 2009, Heo et al. 2009). We and others recently identified Lin28B as one of the main let-7 targets (Boyerinas et al. 2008, Rybak et al. 2008), and it was shown that let-7 and Lin28 are part of a double negative feedback loop regulating expression of let-7, which is conserved from worms to humans (Rybak et al. 2008, Peter 2009). Recently, the $C$. elegans TUTase that uridylates let-7 was identified as PUP-2 (an ortholog of TUT4; Lehrbach et al. 2009). The negative feedback loop that involves Lin28/Lin28B and let-7 also includes c-Myc, which is both a target of let-7 itself (Sampson et al. 2007) as well as a potent regulator of the 


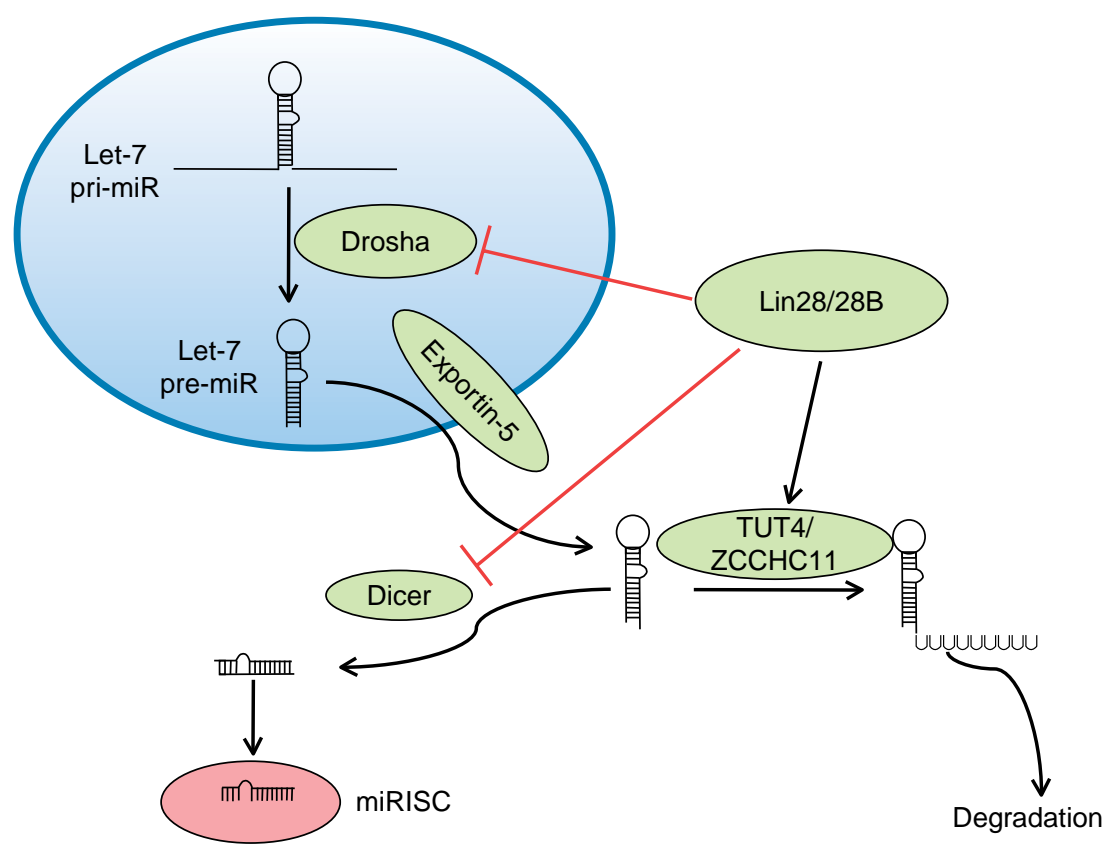

Figure 1 Regulation of the biogenesis of let-7 by Lin28/Lin28B by three different mechanisms. For details see text.

expression of various let-7 family members (Chang et al. 2008b). Recently, it was demonstrated that c-Myc also targets Lin28B causing repression of let-7 without affecting its transcriptional expression adding to the complexity of the feedback loop (Chang et al. 2009, Dangi-Garimella et al. 2009).

The importance of the let- 7 regulators $\operatorname{Lin} 28$ and Lin28B is also emerging from studies demonstrating upregulation of Lin28 or Lin28B in various forms of cancer for which a downregulation of let-7 has been shown. The first demonstration of Lin28B being up-regulated in a human cancer was made for hepatocellular carcinoma (HCC; Guo et al. 2006). In ovarian cancer, an inverse relationship between the expression of let-7a and Lin28B was found, and Lin28B was identified as an unfavorable prognostic marker (Lu et al. 2009). Most recently, Lin 28 and Lin28B were reported to be up-regulated in various forms of cancer including Wilm's tumor, HCC, chronic myeloid leukemia, and ovarian cancer with an overall incidence of about 15\% (Viswanathan et al. 2009). Their overexpression facilitated cellular transformation in various in vitro systems and promoted tumor growth in mouse tumor models. In another study, it was shown that Lin28 enhances metastasis (Dangi-Garimella et al. 2009).

While Lin28 and Lin28B are important in the regulation of let-7 processing, they are also active as stem cell factors, and Lin 28 has been shown together with three other factors (Oct4, Sox2, and Nanog) to be sufficient to reprogram somatic fibroblasts to become pluripotent stem cells (Yu et al. 2007b). Consistently, Lin28 was also reported to be involved in the development of a rare founder population of germ cells (West et al. 2009) and to be frequently up-regulated in germ cell tumors. In fact, Lin28 and Lin28B were more consistently up-regulated in such tumors than even the very potent stem cell factor Oct 4 . All these reports point at a function of Lin28/Lin28B as powerful regulators of stem cells and germ cells. There is evidence that some of these activities involve the regulation of let-7.

While Lin28 and Lin28B are emerging as major regulators of let-7 activity, transcriptional regulation of let-7 has also been reported, and it was shown that pri-let-7 is negatively regulated by a pathway controlled by the microtubulin-associated kinase DCAMKL-1 (Sureban et al. 2009). Furthermore, it was recently demonstrated that Lin28 has additional activities that could contribute to its activity as a stem cell factor. It was shown that Lin 28 promotes production of the replication-dependent histone mRNA H2a and of cyclin A in mouse embryonic stem cells (Xu \& Huang 2009). Hence, the regulation of let-7 levels is unlikely the only activity of Lin28 and Lin28B.

Posttranslational regulation of miR expression is not limited to let-7 (Lu et al. 2005, Thomson et al. 2006), and it is widely expected that Lin28 and Lin28B only represent one example of a new class of regulators of $\mathrm{miR}$ biogenesis. In fact, other factors are emerging that 
have been demonstrated to control let-7 expression. A complex of nuclear factor 90 (NF90) and NF45 was shown to negatively regulate expression of miRs. While NF90-NF45 had a preference for let-7a over miR-21, it also affected processing of other miRs (Sakamoto et al. 2009). The identification of Lin28 and Lin28B is therefore only the tip of the iceberg, and a detailed knowledge of the factors regulating various miRs under different physiological and disease conditions may allow us to correct expression of dysregulated miRs in diseases such as cancer.

\section{miRs and drug sensitivity}

Chemotherapy is one of the most frequently utilized treatment modalities for various forms of human cancer. Unfortunately, the majority of patients in most forms of cancer relapse within 5 years, and recurrent disease is frequently much more resistant to treatment via chemotherapeutic agents. Understanding the mechanisms via which drug resistance evolves in treatment-refractory cancers is critically important in the fight to reduce cancer-related mortalities. Changes in miR expression profiles, due to their profound effect on gene expression signatures, are emerging as an intriguing mechanism for the development of chemoresistance in many cancers (Fig. 2).

A group of miRs has been implicated in modulation of survival pathways and/or apoptotic response in cancer cells. MiR-15b and miR-16 target the antiapoptotic protein $\mathrm{Bcl} 2$ and reduce its expression level (Xia et al. 2008), while miR-1 overexpression sensitizes A549 lung cancer cells to doxorubicininduced death by reducing levels of the anti-apoptotic protein Mcl-1 (Nasser et al. 2008). At least three miRs modulate the PTEN/Akt survival pathway; miR-214 expression induces cell survival and resistance to cisplatin by specifically targeting the PTEN 3 '-UTR (Yang et al. 2008a), miR-205 specifically targets the $3^{\prime}$-UTR of the HER3 receptor and restores sensitivity to Gefitinib via reduction of HER3 protein levels and inhibition of Akt signaling (Iorio et al. 2009), and miR21 expression activates Akt-dependant survival signaling in cholangiocarcinoma cell lines (Meng et al. 2006). Additionally, miRs-221 and 222 maintain a TRAIL-resistant phenotype by targeting p27 in NSCLC (Garofalo et al. 2008). MiR-143 expression sensitizes Jurkat leukemia cells to Fas-mediated apoptosis by directly targeting ERK5 (Akao et al. 2009). p53 transcriptionally induces miR-34a

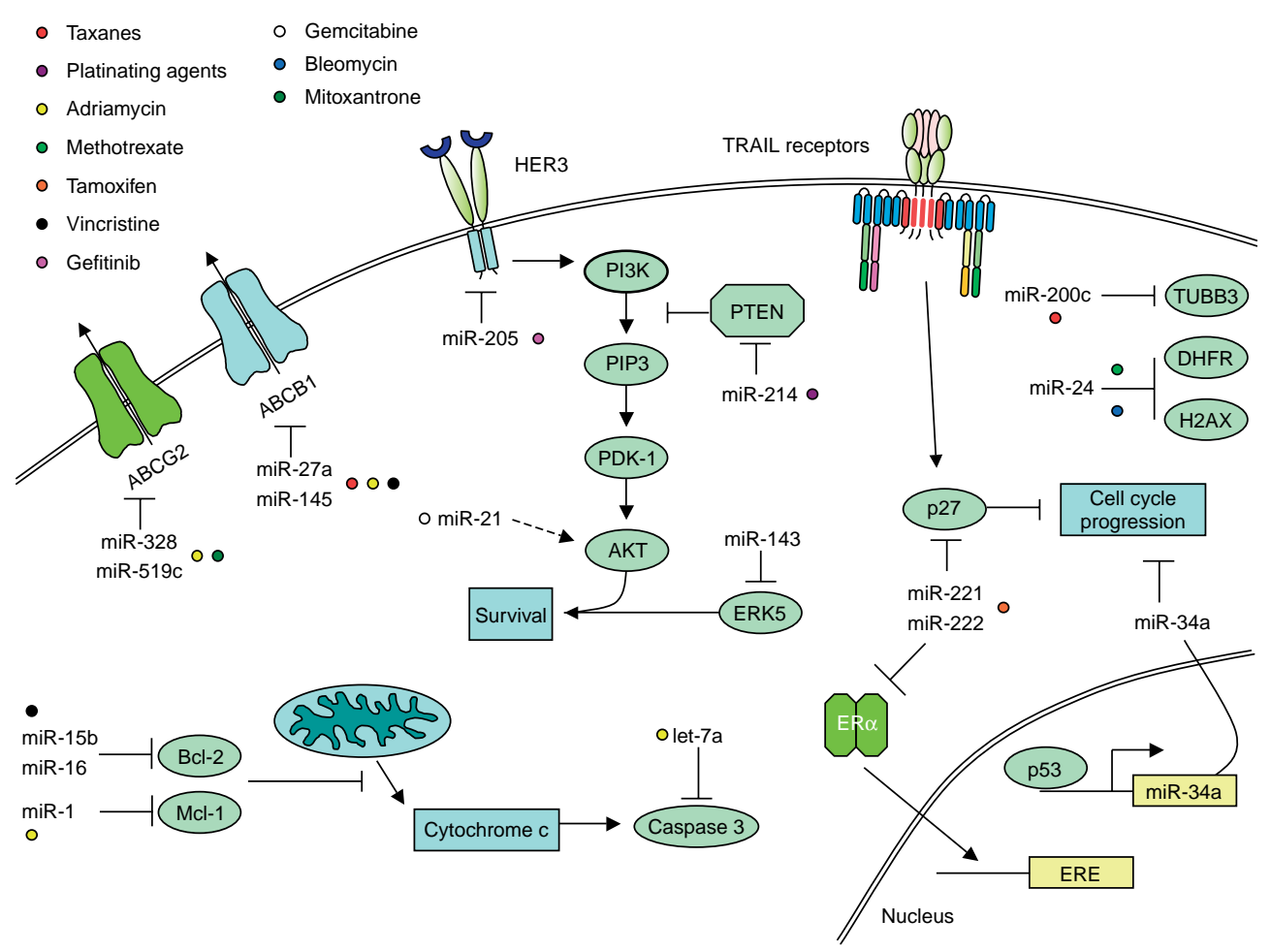

Figure 2 Scheme to illustrate how miRs affect drug sensitivity of cancer cells. In each case, the miRs are not direct inhibiting proteins but are acting by regulating the mRNAs that code for the proteins shown. The drug resistance that was reported to be affected by a specific miR is indicated by a colored dot next to the miR. For details see text. 
expression, which in turn leads to cell cycle arrest and apoptosis induction (Chang et al. 2007).

A second group of miRs has been demonstrated to alter cellular response to a specific drug or class of drugs independently of survival or apoptotic signaling (Fig. 2). MiR-200c targets TUBB3, a tubulin isotype that is generally found only in neurons but is expressed in some cancers with resistance to microtubule-binding agents (Cochrane et al. 2009). MiR-24 targets the $3^{\prime}$-UTR of dihydrofolate reductase (DHFR), and a SNP in the DHFR $3^{\prime}$-UTR that abolishes this regulation leads to methotrexate resistance as a result of DHFR overexpression (Mishra et al. 2007). MiR-24 also sensitizes terminally differentiated blood cells to DNA damage by targeting the $3^{\prime}$-UTR of H2AX and inhibiting the double-strand break response (Lal et al. 2009). MiRs-221 and 222 specifically target the 3 -UTR of estrogen receptor- $\alpha$ and induce tamoxifen resistance in breast cancer cell lines (Lal et al. 2009). Many cancers, especially recurrent cases that occur after prior chemotherapeutic treatment, become resistant to specific classes of drugs - a situation known as multi-drug resistance. This phenotype is mediated in many cases by the overexpression of transmembrane drug efflux pumps that transport drugs from the cytosol to the extracellular space. Recent evidence suggests that expression of two of these pumps, ABCB1 (MDR1) and ABCG2 (BCRP), is directly regulated by miRs. MDR 1 , a drug efflux pump overexpressed in many therapy resistant cancers, is directly regulated by miR-145 and miR-27a. Forced overexpression of these miRs reduces MDR1 protein expression in multi-drug-resistant cancer cell lines and renders them sensitive to MDR1 substrates such as doxorubicin and paclitaxel (Kovalchuk et al. 2008, Zhu et al. 2008). ABCG2 is similarly regulated by miR-328 and miR-519c (To et al. 2008, Pan et al. 2009). Re-introduction of these miRs into cancers with a multi-drug resistant phenotype holds potential as an adjuvant therapy that could potentially sensitize these cancers to chemotherapeutic agents.

As described above, the let-7 family of miRs plays a role in a host of cellular functions, and that includes modulation of drug sensitivity. The most direct mechanistic link between a let-7 family member and drug sensitivity involves let-7a, which has been shown to directly target caspase-3. Let-7a, which is overexpressed in some human cancers, induces resistance to a variety of drugs that induce caspase-3-dependent apoptosis (Tsang \& Kwok 2008). Interestingly, four independent studies have found a correlation between let-7i expression and either sensitivity or resistance to certain compounds. A study on chemotherapy-resistant ovarian cancer patients determined that let-7i is downregulated in resistant cancers, and that reintroduction of let-7i can sensitize resistant ovarian cancer cell lines to platinum-based chemotherapy (Yang et al. 2008b). A second study determined that introducing let-7i into A549 lung cancer cells sensitized them to one of ten novel chemotherapeutic compounds tested but had no effect on the others (Blower et al. 2008). Introducing miR-21, on the other hand, altered the sensitivity of this cell line to six of ten compounds tested. This group, however, did not test additional let-7 family members to determine whether the effect is specific to let-7i. Two studies that performed miR array analysis using either adriamycin or fulvestrant resistant derivatives of MCF7 breast cancer cells came to differing conclusions concerning let-7i. Let-7i was up-regulated in the adriamycin resistant derivative, while it was downregulated in the fulvestrant resistant line (Chen et al. 2009, Xin et al. 2009). It is important to note that neither of these studies determined whether let-7i expression was mechanistically linked to the observed drug resistance.

Let-7 family members have also been shown to be involved in radiation response of cancer cell lines. When A549 lung cancer cells were exposed to ionizing radiation, the expression of all let-7 family members decreased except for let-7g, whose expression increased in response to radiation. Furthermore, introduction of exogenous let- $7 \mathrm{~b}$ radiosensitized these cells, while introduction of let-7g conferred radioprotection (Weidhaas et al. 2007). On the other hand, a similar study using PC3 prostate cancer cells found no change in any let-7 family members following exposure to ionizing radiation (Josson et al. 2008). A third study determined that all let-7 family members were up-regulated in Jurkat T-cell leukemia cells in response to ionizing radiation, with let- $7 \mathrm{f}$ and let- $7 \mathrm{i}$ up-regulated more than fourfold in these cells. Conversely, TK6 human B-lymphoblast cells sharply downregulated let-7d and let-7g in response to irradiation, while modestly upregulating the other family members (Chaudhry 2009). This study did not investigate whether exogenously altering let-7 expression affected response of the cells to ionizing radiation. In summary, it appears as if the let-7 family does play a role in the response to ionizing radiation, but that the role of this involvement may be tissue or cell type specific, potentially depending upon how much let-7 is expressed in a particular cell type.

Cell lines chronically cultured in escalating amounts of chemotherapeutic agents are a common tool used to study mechanisms of drug resistance. One study determined $\mathrm{miR}$ profiles in cisplatin resistant 
(A2780CIS) and Taxane resistant (A2780TAX, A2780TC1, A2780TC3) A2780 ovarian cancer cells. The TC1 and TC3 cells had been derived in the presence of cyclosporine (an inhibitor of MDR1) as well as Taxol, and were 10- and 17-fold more resistant to Taxol respectively. A2780TAX cells were resistant to Taxol due to overexpression of the drug efflux pump MDR1, while the resistance of TC1 and TC3 was determined to be the result of upregulation of the class III isoform of $\beta$-tubulin, to which Taxol cannot efficiently bind. Only the A2780TAX cell line had an alteration in let-7 levels, with let-7e being up-regulated in this cell line. Interestingly, the TC1 and TC 3 cell lines, despite being at least tenfold more resistant to Taxol than the A2780TAX cells, did not upregulate let-7e (Sorrentino et al. 2008). If let-7e upregulation could be linked mechanistically to Taxol resistance in the A2780TAX cells, it would suggest a distinct regulation of drug resistance for this particular let-7 family member that is not applicable to all forms of Taxol resistance. Interestingly, an independent study that correlated miR expression profiles of 16 ovarian cancer cell lines (including A2780 and A2780CP, a cisplatin resistant derivative) with sensitivity to six different chemotherapeutic agents (including docetaxel, doxorubicin, and cisplatin) found that let-7e was up-regulated in cell lines with increased resistance to doxorubicin (Boren et al. 2009). In this study, only seven miRs were significantly correlated with sensitivity or resistance to more than one compound. Of importance, none of the cell lines tested had been selected for acquired resistance to a single agent other than the A2780/A2780CP pair. This suggests that let-7e may be playing a role in both inherent and acquired resistance to particular chemotherapeutic agents. Recently, it was demonstrated that HMGA2 protects cancer cells from DNA damage-inducing reagents such as methyl methanesulphonate (Summer et al. 2009). However, no direct connection between let-7 and this form of drug resistance has been described.

Perhaps, the most provocative evidence linking let-7 to drug sensitivity comes from studies with breast cancer T-IC. The cancer stem cell hypothesis, while still somewhat controversial, suggests that cancers may arise from rare cells with stem-like characteristics such as self-renewal and multi-potent differentiation capability. The hypothesis further suggests that these cells are inherently drug resistant, and that chemotherapy fails in part because of the ability of these cells to survive and repopulate the tumor. Recent evidence has demonstrated that breast cancer T-ICs can be characterized by low let- 7 expression, and that modulating let-7 expression in these cells alters their stem-like properties ( $\mathrm{Yu}$ et al. 2007a). This phenomenon was also observed in comma-D $\beta$, an immortalized but not transformed mouse mammary epithelial cell line that contains a permanent population of undifferentiated progenitor cells that are able to repopulate the mouse mammary tree. These progenitor cells were found to be let-7 low, and enforced let-7 expression eliminated the self-renewing cells from the population (Ibarra et al. 2007). Taken together, these studies suggest that a let-7 low status is common to both T-ICs and normal epithelial progenitor cells.

$\mathrm{Yu}$ et al. initially observed that cells taken from breast cancer patients who had been treated with chemotherapy had greater tumorigenic properties than those obtained from chemotherapy-naïve patients. In order to investigate this phenomenon further and determine the molecular basis, the group devised a method to obtain large amounts of these T-ICs. The cells were derived by serially passaging the SKBR3 breast cancer cell line through NOD/SCID mice that had been injected with epirubicin. The resulting cells (SK3RD) were cultured in an attachment-free culture system and displayed many of the stem-like properties of the cells derived from chemotherapy-treated patients. As with the patient cells, it was determined that SK3RD cells had a much greater ability to proliferate in suspension and form ball-like structures termed mammospheres when compared to parental SKBR3 cells. The cells were highly enriched for a $\mathrm{CD} 44^{+} \mathrm{CD} 24^{-}$lin $^{-}$stem cell marker phenotype, and plating them on collagen under differentiating conditions drastically reduced the number of cells with this phenotype. SK3RD cells were also determined to have significantly greater resistance to epirubicin prior to differentiation and expressed the ABC transporter ABCG2.

The group then performed miR array analysis on SK3RD cells prior to and after differentiation and found that all let-7 family members were expressed at a low level in SK3RD cells but were significantly up-regulated post-differentiation. Furthermore, they determined that introducing let-7 into these cells drastically reduced their tumorigenicity, as determined by their ability to form mammospheres as well as their ability to form serially transplantable tumor xenografts in nude mice. No further investigations were done concerning drug sensitivity, but it is interesting to suggest a hypothesis where a tumor, even one that largely maintains let-7 expression, is populated by let-7 low T-ICs that are more resistant to chemotherapeutic agents than the tumor as a whole. Successful therapy in this scenario would then be predicated on the ability to target these T-ICs. Much work remains, but this initial 
insight into the relationship between let-7 and T-ICs strongly supports the growing body of evidence that let-7-based therapeutics will likely hold significant promise as both a frontline and an adjuvant treatment option for a variety of different cancers.

\section{Outlook}

As we have discussed throughout this review, the let-7 family of miRs plays a role in an exceedingly diverse array of cellular activities. The role of let-7 in the differentiation of multiple cell types across multiple organisms during embryonic development has been firmly established. Furthermore, there is a very clear link between loss of let-7 expression and the development of poorly differentiated, aggressive cancers. As we have elucidated, let-7 expression is regulated on multiple levels, and particular family members appear to be specifically deregulated in certain cancers. Questions remain, however, as to whether 13 let-7 family members exist because they have different activities (targets) or whether that many genes exist to allow a more differentiated regulation in various cell/tissue types. In addition, while the evidence is growing that loss of let-7 increases resistance to certain chemotherapeutic drugs and to radiation, it is at present unknown how this occurs mechanistically because no let-7 target has been identified that would provide an explanation of this activity of let-7. Regardless of the answers to these questions, available data suggest that restoration of let-7 expression to tumors where it has been lost holds great therapeutic potential for the treatment of these aggressive types of cancer.

\section{Declaration of interest}

We declare that there is no conflict of interest that could be perceived as prejudicing the impartiality of the research reported.

\section{Funding}

This research did not receive any specific grant from any funding agency in the public, commercial, or not-forprofit sector.

\section{References}

Abbott AL, Alvarez-Saavedra E, Miska EA, Lau NC, Bartel DP, Horvitz HR \& Ambros V 2005 The let-7 microRNA family members mir-48, mir-84, and mir-241 function together to regulate developmental timing in Caenorhabditis elegans. Developmental Cell 9 403-414.
Akao Y, Nakagawa Y, Iio A \& Naoe T 2009 Role of microRNA-143 in Fas-mediated apoptosis in human T-cell leukemia Jurkat cells. Leukemia Research 33 1530-1538.

Alvarez-Garcia I \& Miska EA 2005 MicroRNA functions in animal development and human disease. Development 132 4653-4662.

Bashirullah A, Pasquinelli AE, Kiger AA, Perrimon N, Ruvkun G \& Thummel CS 2003 Coordinate regulation of small temporal RNAs at the onset of Drosophila metamorphosis. Developmental Biology 259 1-8.

Bethke A, Fielenbach N, Wang Z, Mangelsdorf DJ \& Antebi A 2009 Nuclear hormone receptor regulation of microRNAs controls developmental progression. Science 324 95-98.

Blower PE, Chung JH, Verducci JS, Lin S, Park JK, Dai Z, Liu CG, Schmittgen TD, Reinhold WC, Croce CM et al. 2008 MicroRNAs modulate the chemosensitivity of tumor cells. Molecular Cancer Therapeutics 7 1-9.

Boren T, Xiong Y, Hakam A, Wenham R, Apte S, Chan G, Kamath SG, Chen DT, Dressman H \& Lancaster JM 2009 MicroRNAs and their target messenger RNAs associated with ovarian cancer response to chemotherapy. Gynecologic Oncology 113 249-255.

Boyerinas B, Park SM, Shomron N, Hedegaard MM, Vinther J, Andersen JS, Feig C, Xu J, Burge CB \& Peter ME 2008 Identification of let-7-regulated oncofetal genes.

Cancer Research 68 2587-2591.

Brueckner B, Stresemann C, Kuner R, Mund C, Musch T, Meister M, Sultmann H \& Lyko F 2007 The human let-7a-3 locus contains an epigenetically regulated microRNA gene with oncogenic function. Cancer Research 67 1419-1423.

Bussing I, Slack FJ \& Grosshans H 2008 Let-7 microRNAs in development, stem cells and cancer. Trends in Molecular Medicine 14 400-409.

Caygill EE \& Johnston LA 2008 Temporal regulation of metamorphic processes in Drosophila by the let-7 and miR-125 heterochronic microRNAs. Current Biology 18 943-950.

Chang TC, Wentzel EA, Kent OA, Ramachandran K, Mullendore M, Lee KH, Feldmann G, Yamakuchi M, Ferlito M, Lowenstein CJ et al. 2007 Transactivation of miR-34a by p53 broadly influences gene expression and promotes apoptosis. Molecular Cell 26 745-752.

Chang SS, Jiang WW, Smith I, Poeta LM, Begum S, Glazer C, Shan S, Westra W, Sidransky D \& Califano JA $2008 a$ MicroRNA alterations in head and neck squamous cell carcinoma. International Journal of Cancer 123 2791-2797.

Chang TC, Yu D, Lee YS, Wentzel EA, Arking DE, West KM, Dang CV, Thomas-Tikhonenko A \& Mendell JT 2008b Widespread microRNA repression by Myc contributes to tumorigenesis. Nature Genetics 40 43-50.

Chang TC, Zeitels LR, Hwang HW, Chivukula RR, Wentzel EA, Dews M, Jung J, Gao P, Dang CV, Beer MA et al. 2009 Lin-28B transactivation is necessary for Mycmediated let-7 repression and proliferation. PNAS 106 3384-3389. 
Chaudhry MA 2009 Real-time PCR analysis of micro-RNA expression in ionizing radiation-treated cells. Cancer Biotherapy \& Radio Pharmaceuticals 24 49-56.

Chen GQ, Zhao ZW, Zhou HY, Liu YJ \& Yang HJ 2009 Systematic analysis of microRNA involved in resistance of the MCF-7 human breast cancer cell to doxorubicin. Medical Oncology [in press].

Childs G, Fazzari M, Kung G, Kawachi N, BrandweinGensler M, McLemore M, Chen Q, Burk RD, Smith RV, Prystowsky MB et al. 2009 Low-level expression of microRNAs let-7d and miR-205 are prognostic markers of head and neck squamous cell carcinoma. American Journal of Pathology 174 736-745.

Chin LJ, Ratner E, Leng S, Zhai R, Nallur S, Babar I, Muller RU, Straka E, Su L, Burki EA et al. 2008 A SNP in a let-7 microRNA complementary site in the KRAS $3^{\prime}$ untranslated region increases non-small cell lung cancer risk. Cancer Research 68 8535-8540.

Christensen BC, Moyer BJ, Avissar M, Ouellet LG, Plaza SL, McClean MD, Marsit CJ \& Kelsey KT 2009 A let-7 microRNA-binding site polymorphism in the KRAS $3^{\prime}$ UTR is associated with reduced survival in oral cancers. Carcinogenesis 30 1003-1007.

Cochrane DR, Spoelstra NS, Howe EN, Nordeen SK \& Richer JK 2009 MicroRNA-200c mitigates invasiveness and restores sensitivity to microtubule-targeting chemotherapeutic agents. Molecular Cancer Therapeutics [in press].

Cullen BR 2004 Transcription and processing of human microRNA precursors. Molecular Cell 16 861-865.

Dahiya N, Sherman-Baust CA, Wang TL, Davidson B, Shih Ie M, Zhang Y, Wood W III, Becker KG \& Morin PJ 2008 MicroRNA expression and identification of putative miRNA targets in ovarian cancer. PLoS ONE 3 e2436.

Dangi-Garimella S, Yun J, Eves EM, Newman M, Erkeland SJ, Hammond SM, Minn AJ \& Rosner MR 2009 Raf kinase inhibitory protein suppresses a metastasis signalling cascade involving LIN28 and let-7. EMBO Journal 28 347-358.

Ding XC, Slack FJ \& Grosshans H 2008 The let-7 microRNA interfaces extensively with the translation machinery to regulate cell differentiation. Cell Cycle 7 3083-3090.

Esquela-Kerscher A, Johnson SM, Bai L, Saito K, Partridge J, Reinert KL \& Slack FJ 2005 Post-embryonic expression of C. elegans microRNAs belonging to the lin- 4 and let-7 families in the hypodermis and the reproductive system. Developmental Dynamics 234 868-877.

Esquela-Kerscher A, Trang P, Wiggins JF, Patrawala L, Cheng A, Ford L, Weidhaas JB, Brown D, Bader AG \& Slack FJ 2008 The let-7 microRNA reduces tumor growth in mouse models of lung cancer. Cell Cycle 7 759-764.

Forman JJ, Legesse-Miller A \& Coller HA 2008 A search for conserved sequences in coding regions reveals that the let-7 microRNA targets Dicer within its coding sequence. PNAS 105 14879-14884.
Garofalo M, Quintavalle C, Di Leva G, Zanca C, Romano G, Taccioli C, Liu CG, Croce CM \& Condorelli G 2008 MicroRNA signatures of TRAIL resistance in human non-small cell lung cancer. Oncogene 27 3845-3855.

Grosshans H, Johnson T, Reinert KL, Gerstein M \& Slack FJ 2005 The temporal patterning microRNA let-7 regulates several transcription factors at the larval to adult transition in C. elegans. Developmental Cell 8 321-330.

Gu J \& Iyer VR 2006 PI3K signaling and miRNA expression during the response of quiescent human fibroblasts to distinct proliferative stimuli. Genome Biology 7 R42.

Guled M, Lahti L, Lindholm PM, Salmenkivi K, Bagwan I, Nicholson AG \& Knuutila S 2009 CDKN2A, NF2, and JUN are dysregulated among other genes by miRNAs in malignant mesothelioma - A miRNA microarray analysis. Genes, Chromosomes \& Cancer 48 615-623.

Guo Y, Chen Y, Ito H, Watanabe A, Ge X, Kodama T \& Aburatani H 2006 Identification and characterization of lin-28 homolog B (LIN28B) in human hepatocellular carcinoma. Gene 384 51-61.

Hagan JP, Piskounova E \& Gregory RI 2009 Lin28 recruits the TUTase Zcchc11 to inhibit let-7 maturation in mouse embryonic stem cells. Nature Structural \& Molecular Biology 16 1021-1025.

Hayes GD \& Ruvkun G 2006 Misexpression of the Caenorhabditis elegans miRNA let-7 is sufficient to drive developmental programs. Cold Spring Harbor Symposia on Quantitative Biology 71 21-27.

Heo I, Joo C, Cho J, Ha M, Han J \& Kim VN 2008 Lin28 mediates the terminal uridylation of let-7 precursor microRNA. Molecular Cell 32 276-284.

Heo I, Joo C, Kim YK, Ha M, Yoon MJ, Cho J, Yeom KH, Han J \& Kim VN 2009 TUT4 in concert with Lin28 suppresses microRNA biogenesis through pre-microRNA uridylation. Cell 138 696-708.

Huang JC, Babak T, Corson TW, Chua G, Khan S, Gallie BL, Hughes TR, Blencowe BJ, Frey BJ \& Morris QD 2007 Using expression profiling data to identify human microRNA targets. Nature Methods 4 1045-1049.

Hutvagner G, McLachlan J, Pasquinelli AE, Balint E, Tuschl T \& Zamore PD 2001 A cellular function for the RNA-interference enzyme Dicer in the maturation of the let-7 small temporal RNA. Science 293 834-838.

Ibarra I, Erlich Y, Muthuswamy SK, Sachidanandam R \& Hannon GJ 2007 A role for microRNAs in maintenance of mouse mammary epithelial progenitor cells. Genes and Development 21 3238-3243.

Iliopoulos D, Bimpaki EI, Nesterova M \& Stratakis CA 2009 MicroRNA signature of primary pigmented nodular adrenocortical disease: clinical correlations and regulation of Wnt signaling. Cancer Research 69 3278-3282.

Iorio MV, Casalini P, Piovan C, Di Leva G, Merlo A, Triulzi T, Menard S, Croce CM \& Tagliabue E 2009 MicroRNA205 regulates HER3 in human breast cancer. Cancer Research 69 2195-2200. 
Johnson SM, Grosshans H, Shingara J, Byrom M, Jarvis R, Cheng A, Labourier E, Reinert KL, Brown D \& Slack FJ 2005 RAS is regulated by the let-7 microRNA family. Cell 120 635-647.

Johnson CD, Esquela-Kerscher A, Stefani G, Byrom M, Kelnar K, Ovcharenko D, Wilson M, Wang X, Shelton J, Shingara J et al. 2007 The let-7 microRNA represses cell proliferation pathways in human cells. Cancer Research 67 7713-7722.

Josson S, Sung SY, Lao K, Chung LW \& Johnstone PA 2008 Radiation modulation of microRNA in prostate cancer cell lines. Prostate 68 1599-1606.

Jovanovic M \& Hengartner MO 2006 miRNAs and apoptosis: RNAs to die for. Oncogene 25 6176-6187.

Kent OA \& Mendell JT 2006 A small piece in the cancer puzzle: microRNAs as tumor suppressors and oncogenes. Oncogene 25 6188-6196.

Ketting RF, Fischer SE, Bernstein E, Sijen T, Hannon GJ \& Plasterk RH 2001 Dicer functions in RNA interference and in synthesis of small RNA involved in developmental timing in C. elegans. Genes and Development 15 2654-2659.

Kim HH, Kuwano Y, Srikantan S, Lee EK, Martindale JL \& Gorospe M 2009 HuR recruits let-7/RISC to repress c-Myc expression. Genes and Development 23 1743-1748.

Kloosterman WP, Wienholds E, Ketting RF \& Plasterk RH 2004 Substrate requirements for let-7 function in the developing zebrafish embryo. Nucleic Acids Research 32 6284-6291.

Kovalchuk O, Filkowski J, Meservy J, Ilnytskyy Y, Tryndyak VP, Chekhun VF \& Pogribny IP 2008 Involvement of microRNA-451 in resistance of the MCF-7 breast cancer cells to chemotherapeutic drug doxorubicin. Molecular Cancer Therapeutics 7 2152-2159.

Kumar MS, Erkeland SJ, Pester RE, Chen CY, Ebert MS, Sharp PA \& Jacks T 2008 Suppression of non-small cell lung tumor development by the let-7 microRNA family. PNAS 105 3903-3908.

Lagos-Quintana M, Rauhut R, Lendeckel W \& Tuschl T 2001 Identification of novel genes coding for small expressed RNAs. Science 294 853-858.

Lai EC 2002 Micro RNAs are complementary to $3^{\prime}$ UTR sequence motifs that mediate negative post-transcriptional regulation. Nature Genetics 30 363-364.

Lal A, Pan Y, Navarro F, Dykxhoorn DM, Moreau L, Meire E, Bentwich Z, Lieberman J \& Chowdhury D 2009 miR-24-mediated downregulation of H2AX suppresses DNA repair in terminally differentiated blood cells. Nature Structural \& Molecular Biology 16 492-498.

Lancman JJ, Caruccio NC, Harfe BD, Pasquinelli AE, Schageman JJ, Pertsemlidis A \& Fallon JF 2005 Analysis of the regulation of lin-41 during chick and mouse limb development. Developmental Dynamics 234 948-960.

Lau NC, Lim LP, Weinstein EG \& Bartel DP 2001 An abundant class of tiny RNAs with probable regulatory roles in Caenorhabditis elegans. Science 294 858-862.
Lawrie CH, Chi J, Taylor S, Tramonti D, Ballabio E, Palazzo S, Saunders NJ, Pezzella F, Boultwood J, Wainscoat JS et al. 2008 Expression of microRNAs in diffuse large B cell lymphoma is associated with immunophenotype, survival, and transformation from follicular lymphoma. Journal of Cellular and Molecular Medicine $\mathbf{1 3}$ 1248-1260.

Lee RC \& Ambros V 2001 An extensive class of small RNAs in Caenorhabditis elegans. Science 294 862-864.

Lee YS \& Dutta A 2007 The tumor suppressor microRNA let-7 represses the HMGA2 oncogene. Genes and Development 21 1025-1030.

Lee RC, Feinbaum RL \& Ambros V 1993 The C. elegans heterochronic gene lin-4 encodes small RNAs with antisense complementarity to lin-14. Cell 75 843-854.

Lee Y, Ahn C, Han J, Choi H, Kim J, Yim J, Lee J, Provost P, Radmark O, Kim S et al. 2003 The nuclear RNase III Drosha initiates microRNA processing. Nature $\mathbf{4 2 5}$ 415-419.

Legesse-Miller A, Elemento O, Pfau SJ, Forman JJ, Tavazoie S \& Coller HA 2009 let-7 Overexpression leads to an increased fraction of cells in G2/M, direct downregulation of $\mathrm{Cdc} 34$, and stabilization of Wee1 kinase in primary fibroblasts. Journal of Biological Chemistry 284 6605-6609.

Lehrbach NJ, Armisen J, Lightfoot HL, Murfitt KJ, Bugaut A, Balasubramanian S \& Miska EA 2009 LIN-28 and the poly(U) polymerase PUP-2 regulate let-7 microRNA processing in Caenorhabditis elegans. Nature Structural \& Molecular Biology 16 1016-1020.

Lettre G, Jackson AU, Gieger C, Schumacher FR, Berndt SI, Sanna S, Eyheramendy S, Voight BF, Butler JL, Guiducci C et al. 2008 Identification of ten loci associated with height highlights new biological pathways in human growth. Nature Genetics 40 584-591.

Leucci E, Cocco M, Onnis A, De Falco G, van Cleef P, Bellan C, van Rijk A, Nyagol J, Byakika B, Lazzi S et al. 2008 MYC translocation-negative classical Burkitt lymphoma cases: an alternative pathogenetic mechanism involving miRNA deregulation. Journal of Pathology 216 440-450.

Li M, Jones-Rhoades MW, Lau NC, Bartel DP \& Rougvie AE 2005 Regulatory mutations of mir-48, a C. elegans let-7 family microRNA, cause developmental timing defects. Developmental Cell 9 415-422.

Lin YC, Hsieh LC, Kuo MW, Yu J, Kuo HH, Lo WL, Lin RJ, Yu AL \& Li WH 2007 Human TRIM71 and its nematode homologue are targets of let-7 microRNA and its zebrafish orthologue is essential for development. Molecular Biology and Evolution 24 2525-2534.

Liu S, Xia Q, Zhao P, Cheng T, Hong K \& Xiang Z 2007 Characterization and expression patterns of let-7 microRNA in the silkworm (Bombyx mori). BMC Developmental Biology 788.

Lu J, Getz G, Miska EA, Alvarez-Saavedra E, Lamb J, Peck D, Sweet-Cordero A, Ebert BL, Mak RH, Ferrando AA et al. 2005 MicroRNA expression profiles classify human cancers. Nature 435 834-838. 
Lu L, Katsaros D, de la Longrais IA, Sochirca O \& Yu H 2007 Hypermethylation of let-7a-3 in epithelial ovarian cancer is associated with low insulin-like growth factor-II expression and favorable prognosis. Cancer Research 67 10117-10122.

Lu L, Katsaros D, Shaverdashvili K, Qian B, Wu Y, de la Longrais IA, Preti M, Menato G \& Yu H 2009 Pluripotent factor lin-28 and its homologue lin-28b in epithelial ovarian cancer and their associations with disease outcomes and expression of let-7a and IGF-II. European Journal of Cancer 45 2212-2218.

Maes OC, Sarojini H \& Wang E 2009 Stepwise up-regulation of microRNA expression levels from replicating to reversible and irreversible growth arrest states in WI-38 human fibroblasts. Journal of Cellular Physiology 221 109-119.

Mathonnet G, Fabian MR, Svitkin YV, Parsyan A, Huck L, Murata T, Biffo S, Merrick WC, Darzynkiewicz E, Pillai RS et al. 2007 MicroRNA inhibition of translation initiation in vitro by targeting the cap-binding complex eIF4F. Science 317 1764-1767.

Mayr C, Hemann MT \& Bartel DP 2007 Disrupting the pairing between let-7 and Hmga2 enhances oncogenic transformation. Science 315 1576-1579.

Meng F, Henson R, Lang M, Wehbe H, Maheshwari S, Mendell JT, Jiang J, Schmittgen TD \& Patel T 2006 Involvement of human micro-RNA in growth and response to chemotherapy in human cholangiocarcinoma cell lines. Gastroenterology 130 2113-2129.

Mi S, Lu J, Sun M, Li Z, Zhang H, Neilly MB, Wang Y, Qian Z, Jin J, Zhang Y et al. 2007 MicroRNA expression signatures accurately discriminate acute lymphoblastic leukemia from acute myeloid leukemia. PNAS 104 19971-19976.

Mishra PJ, Humeniuk R, Longo-Sorbello GS, Banerjee D \& Bertino JR 2007 A miR-24 microRNA binding-site polymorphism in dihydrofolate reductase gene leads to methotrexate resistance. PNAS 104 13513-13518.

Muller DW \& Bosserhoff AK 2008 Integrin beta 3 expression is regulated by let-7a miRNA in malignant melanoma. Oncogene 27 6698-6706.

Nam EJ, Yoon H, Kim SW, Kim H, Kim YT, Kim JH, Kim JW \& Kim S 2008 MicroRNA expression profiles in serous ovarian carcinoma. Clinical Cancer Research 14 2690-2695.

Narita M, Krizhanovsky V, Nunez S, Chicas A, Hearn SA, Myers MP \& Lowe SW 2006 A novel role for highmobility group a proteins in cellular senescence and heterochromatin formation. Cell 126 503-514.

Nasser MW, Datta J, Nuovo G, Kutay H, Motiwala T, Majumder S, Wang B, Suster S, Jacob ST \& Ghoshal K 2008 Down-regulation of micro-RNA-1 (miR-1) in lung cancer. Suppression of tumorigenic property of lung cancer cells and their sensitization to doxorubicininduced apoptosis by miR-1. Journal of Biological Chemistry 283 33394-33405.
Newman MA, Thomson JM \& Hammond S 2008 Lin-28 interaction with the let-7 precursor loop mediates regulated microRNA processing. RNA 14 1539-1549.

Nie K, Gomez M, Landgraf P, Garcia JF, Liu Y, Tan LH, Chadburn A, Tuschl T, Knowles DM \& Tam W 2008 MicroRNA-mediated down-regulation of PRDM1/ Blimp-1 in Hodgkin/Reed-Sternberg cells: a potential pathogenetic lesion in Hodgkin lymphomas. American Journal of Pathology 173 242-252.

Nishino J, Kim I, Chada K \& Morrison SJ 2008 Hmga2 promotes neural stem cell self-renewal in young but not old mice by reducing p16Ink4a and p19Arf expression. Cell 135 227-239.

O'Farrell F, Esfahani SS, Engstrom Y \& Kylsten P 2008 Regulation of the Drosophila lin-41 homologue dappled by let-7 reveals conservation of a regulatory mechanism within the LIN-41 subclade. Developmental Dynamics 237 196-208.

O’Hara AJ, Wang L, Dezube BJ, Harrington WJ Jr, Damania B \& Dittmer DP 2009 Tumor suppressor microRNAs are underrepresented in primary effusion lymphoma and Kaposi sarcoma. Blood 113 5938-5941.

Ozen M, Creighton CJ, Ozdemir M \& Ittmann M 2008 Widespread deregulation of microRNA expression in human prostate cancer. Oncogene 27 1788-1793.

Pan YZ, Morris ME \& Yu AM 2009 MicroRNA-328 negatively regulates the expression of breast cancer resistance protein (BCRP/ABCG2) in human cancer cells. Molecular Pharmacology 75 1374-1379.

Park SM, Shell S, Radjabi AR, Schickel R, Feig C, Boyerinas B, Dinulescu DM, Lengyel E \& Peter ME 2007 Let-7 prevents early cancer progression by suppressing expression of the embryonic gene HMGA2. Cell Cycle 6 2585-2590.

Pasquinelli AE, Reinhart BJ, Slack F, Martindale MQ, Kuroda MI, Maller B, Hayward DC, Ball EE, Degnan B, Muller P et al. 2000 Conservation of the sequence and temporal expression of let-7 heterochronic regulatory RNA. Nature 408 86-89.

Peng Y, Laser J, Shi G, Mittal K, Melamed J, Lee P \& Wei JJ 2008 Antiproliferative effects by let-7 repression of high-mobility group A2 in uterine leiomyoma. Molecular Cancer Research 6 663-673.

Peter ME 2009 Let-7 and miR-200 microRNAs: guardians against pluripotency and cancer progression. Cell Cycle $\mathbf{8}$ 843-852.

Piskounova E, Viswanathan SR, Janas M, Lapierre RJ, Daley GQ, Sliz P \& Gregory RI 2008 Determinants of microRNA processing inhibition by the developmentally regulated RNA-binding protein Lin28. Journal of Biological Chemistry 283 21310-21314.

Qian ZR, Asa SL, Siomi H, Siomi MC, Yoshimoto K, Yamada S, Wang EL, Rahman MM, Inoue H, Itakura M et al. 2009 Overexpression of HMGA2 relates to reduction of the let-7 and its relationship to clinicopathological features in pituitary adenomas. Modern Pathology 22 431-441. 
Reinhart BJ, Slack FJ, Basson M, Pasquinelli AE, Bettinger JC, Rougvie AE, Horvitz HR \& Ruvkun G 2000 The 21-nucleotide let-7 RNA regulates developmental timing in Caenorhabditis elegans. Nature $\mathbf{4 0 3}$ 901-906.

Roush S \& Slack FJ 2008 The let-7 family of microRNAs. Trends in Cell Biology 18 505-516.

Ruby JG, Jan C, Player C, Axtell MJ, Lee W, Nusbaum C, Ge H \& Bartel DP 2006 Large-scale sequencing reveals 21U-RNAs and additional microRNAs and endogenous siRNAs in C. elegans. Cell 127 1193-1207.

Rybak A, Fuchs H, Smirnova L, Brandt C, Pohl EE, Nitsch R \& Wulczyn FG 2008 A feedback loop comprising lin-28 and let-7 controls pre-let-7 maturation during neural stemcell commitment. Nature Cell Biology 10 987-993.

Sakamoto S, Aoki K, Higuchi T, Todaka H, Morisawa K, Tamaki N, Hatano E, Fukushima A, Taniguchi T \& Agata Y 2009 The NF90-NF45 complex functions as a negative regulator in the microRNA processing pathway. Molecular and Cellular Biology 29 3754-3769.

Sampson VB, Rong NH, Han J, Yang Q, Aris V, Soteropoulos P, Petrelli NJ, Dunn SP \& Krueger LJ 2007 MicroRNA let-7a down-regulates MYC and reverts MYC-induced growth in Burkitt lymphoma cells. Cancer Research 67 9762-9770.

Schickel R, Boyerinas B, Park SM \& Peter ME 2008 MicroRNAs: key players in the immune system, differentiation, tumorigenesis and cell death. Oncogene 27 5959-5974.

Schulman BR, Esquela-Kerscher A \& Slack FJ 2005 Reciprocal expression of lin-41 and the microRNAs let-7 and mir-125 during mouse embryogenesis. Developmental Dynamics 234 1046-1054.

Schultz J, Lorenz P, Gross G, Ibrahim S \& Kunz M 2008 MicroRNA let-7b targets important cell cycle molecules in malignant melanoma cells and interferes with anchorage-independent growth. Cell Research 18 549-557.

Sempere LF, Dubrovsky EB, Dubrovskaya VA, Berger EM \& Ambros V 2002 The expression of the let-7 small regulatory RNA is controlled by ecdysone during metamorphosis in Drosophila melanogaster. Developmental Biology 244 170-179.

Sempere LF, Freemantle S, Pitha-Rowe I, Moss E, Dmitrovsky E \& Ambros V 2004 Expression profiling of mammalian microRNAs uncovers a subset of brainexpressed microRNAs with possible roles in murine and human neuronal differentiation. Genome Biology 5 R13.

Sempere LF, Christensen M, Silahtaroglu A, Bak M, Heath CV, Schwartz G, Wells W, Kauppinen S \& Cole CN 2007 Altered microRNA expression confined to specific epithelial cell subpopulations in breast cancer. Cancer Research 67 11612-11620.

Shell S, Park SM, Radjabi AR, Schickel R, Kistner EO, Jewell DA, Feig C, Lengyel E \& Peter ME 2007 Let-7 expression defines two differentiation stages of cancer. PNAS 104 11400-11405.
Sokol NS, Xu P, Jan YN \& Ambros V 2008 Drosophila let-7 microRNA is required for remodeling of the neuromusculature during metamorphosis. Genes and Development 22 1591-1596.

Sorrentino A, Liu CG, Addario A, Peschle C, Scambia G \& Ferlini C 2008 Role of microRNAs in drug-resistant ovarian cancer cells. Gynecologic Oncology 111 478-486.

Stefani G \& Slack FJ 2008 Small non-coding RNAs in animal development. Nature Review. Molecular and Cellular Biology 9 219-230.

Subramanian S, Lui WO, Lee CH, Espinosa I, Nielsen TO, Heinrich MC, Corless CL, Fire AZ \& van de Rijn M 2008 MicroRNA expression signature of human sarcomas. Oncogene 27 2015-2026.

Summer H, Li O, Bao Q, Zhan L, Peter S, Sathiyanathan P, Henderson D, Klonisch T, Goodman SD \& Droge P 2009 HMGA2 exhibits dRP/AP site cleavage activity and protects cancer cells from DNA-damage-induced cytotoxicity during chemotherapy. Nucleic Acids Research 37 4371-4384.

Sun T, Fu M, Bookout AL, Kliewer SA \& Mangelsdorf DJ 2009 MicroRNA let-7 regulates 3T3-L1 adipogenesis. Molecular Endocrinology 23 925-931.

Sureban SM, May R, Ramalingam S, Subramaniam D, Natarajan G, Anant S \& Houchen CW 2009 Selective blockade of DCAMKL-1 results in tumor growth arrest by a let-7a microRNA-dependent mechanism. Gastroenterology 137 649-659.

Takamizawa J, Konishi H, Yanagisawa K, Tomida S, Osada H, Endoh H, Harano T, Yatabe Y, Nagino M, Nimura Y et al. 2004 Reduced expression of the let-7 microRNAs in human lung cancers in association with shortened postoperative survival. Cancer Research 64 3753-3756.

Thomson JM, Parker J, Perou CM \& Hammond SM 2004 A custom microarray platform for analysis of microRNA gene expression. Nature Methods 1 47-53.

Thomson JM, Newman M, Parker JS, Morin-Kensicki EM, Wright T \& Hammond SM 2006 Extensive posttranscriptional regulation of microRNAs and its implications for cancer. Genes Development 20 2202-2207.

To KK, Zhan Z, Litman T \& Bates SE 2008 Regulation of ABCG2 expression at the $3^{\prime}$ untranslated region of its mRNA through modulation of transcript stability and protein translation by a putative microRNA in the $\mathrm{S} 1$ colon cancer cell line. Molecular and Cellular Biology $\mathbf{2 8}$ 5147-5161.

Tokumaru S, Suzuki M, Yamada H, Nagino M \& Takahashi T 2008 Let-7 regulates Dicer expression and constitutes a negative feedback loop. Carcinogenesis 29 2073-2077.

Torrisani J, Bournet B, du Rieu MC, Bouisson M, Souque A, Escourrou J, Buscail L \& Cordelier P 2009 Let-7 microRNA rransfer in pancreatic cancer-derived cells inhibits in vitro cell proliferation but fails to alter tumor progression. Human Gene Therapy 20 831-844. 
Tsang WP \& Kwok TT 2008 Let-7a microRNA suppresses therapeutics-induced cancer cell death by targeting caspase-3. Apoptosis 13 1215-1222.

Vasudevan S, Tong Y \& Steitz JA 2007 Switching from repression to activation: microRNAs can up-regulate translation. Science 318 1931-1934.

Viswanathan SR, Daley GQ \& Gregory RI 2008 Selective blockade of microRNA processing by lin-28. Science $\mathbf{3 2 0}$ 97-100.

Viswanathan SR, Powers JT, Einhorn W, Hoshida Y, Ng TL, Toffanin S, O'Sullivan M, Lu J, Phillips LA, Lockhart VL et al. 2009 Lin 28 promotes transformation and is associated with advanced human malignancies. Nature Genetics 41 843-848.

Wagner W, Horn P, Castoldi M, Diehlmann A, Bork S, Saffrich R, Benes V, Blake J, Pfister S, Eckstein V et al. 2008 Replicative senescence of mesenchymal stem cells: a continuous and organized process. PLOS ONE 3 e2213.

Watanabe S, Ueda Y, Akaboshi S, Hino Y, Sekita Y \& Nakao M 2009 HMGA2 maintains oncogenic RAS-induced epithelial-mesenchymal transition in human pancreatic cancer cells. American Journal of Pathology 174 854-868.

Weidhaas JB, Babar I, Nallur SM, Trang P, Roush S, Boehm M, Gillespie E \& Slack FJ 2007 MicroRNAs as potential agents to alter resistance to cytotoxic anticancer therapy. Cancer Research 67 11111-11116.

West JA, Viswanathan SR, Yabuuchi A, Cunniff K, Takeuchi A, Park IH, Sero JE, Zhu H, Perez-Atayde A, Frazier AL et al. 2009 A role for lin28 in primordial germ-cell development and germ-cell malignancy. Nature 460 909-913.

Wulczyn FG, Smirnova L, Rybak A, Brandt C, Kwidzinski E, Ninnemann O, Strehle M, Seiler A, Schumacher S \& Nitsch R 2007 Post-transcriptional regulation of the let-7 microRNA during neural cell specification. FASEB Journal 21 415-426.

Xia L, Zhang D, Pan Y, Zhao L, Sun S, Hong L, Liu J \& Fan D 2008 miR-15b and miR-16 modulate multidrug resistance by targeting BCL2 in human gastric cancer cells. International Journal of Cancer 123 372-379.

Xin F, Li M, Balch C, Thomson M, Fan M, Liu Y, Hammond SM, Kim S \& Nephew KP 2009 Computational analysis of microRNA profiles and their target genes suggests significant involvement in breast cancer antiestrogen resistance. Bioinformatics 25 430-434.
Xu B \& Huang Y 2009 Histone H2a mRNA interacts with Lin28 and contains a Lin28-dependent posttranscriptional regulatory element. Nucleic Acids Research 37 4256-4263.

Yan LX, Huang XF, Shao Q, Huang MY, Deng L, Wu QL, Zeng YX \& Shao JY 2008 MicroRNA miR-21 overexpression in human breast cancer is associated with advanced clinical stage, lymph node metastasis and patient poor prognosis. RNA 14 2348-2360.

Yanaihara N, Caplen N, Bowman E, Seike M, Kumamoto K, Yi M, Stephens RM, Okamoto A, Yokota J, Tanaka T et al. 2006 Unique microRNA molecular profiles in lung cancer diagnosis and prognosis. Cancer Cell 9 189-198.

Yang H, Kong W, He L, Zhao JJ, O’Donnell JD, Wang J, Wenham RM, Coppola D, Kruk PA, Nicosia SV et al. $2008 a$ MicroRNA expression profiling in human ovarian cancer: miR-214 induces cell survival and cisplatin resistance by targeting PTEN. Cancer Research 68 425-433.

Yang N, Kaur S, Volinia S, Greshock J, Lassus H, Hasegawa K, Liang S, Leminen A, Deng S, Smith L et al. 2008 b MicroRNA microarray identifies let-7i as a novel biomarker and therapeutic target in human epithelial ovarian cancer. Cancer Research 68 10307-10314.

Yi R, Qin Y, Macara IG \& Cullen BR 2003 Exportin-5 mediates the nuclear export of pre-microRNAs and short hairpin RNAs. Genes and Development 17 3011-3016.

Yu F, Yao H, Zhu P, Zhang X, Pan Q, Gong C, Huang Y, Hu $\mathrm{X}, \mathrm{Su}$ F, Lieberman J et al. $2007 a$ Let-7 regulates self renewal and tumorigenicity of breast cancer cells. Cell 131 1109-1123.

Yu J, Vodyanik MA, Smuga-Otto K, Antosiewicz-Bourget J, Frane JL, Tian S, Nie J, Jonsdottir GA, Ruotti V, Stewart $\mathrm{R}$ et al. $2007 b$ Induced pluripotent stem cell lines derived from human somatic cells. Science 318 1917-1920.

Zhou X, Benson KF, Ashar HR \& Chada K 1995 Mutation responsible for the mouse pygmy phenotype in the developmentally regulated factor HMGI-C. Nature 376 771-774.

Zhu H, Wu H, Liu X, Evans BR, Medina DJ, Liu CG \& Yang JM 2008 Role of microRNA miR-27a and miR451 in the regulation of MDR1/P-glycoprotein expression in human cancer cells. Biochemical Pharmacology 76 582-588. 